\title{
Byproducts from cassava industry: alternative substrates for cyclodextrin glycosyltransferase production by alkalophilic Bacillus trypoxylicola SM-02
}

Carine Mascena Peixoto ${ }^{1}$, Sheila Lorena de Araújo Coelho ${ }^{1}$ \& Marcia Luciana Cazetta ${ }^{2}$

1 Center of Agricultural, Environmental, and Biological Sciences, Federal University of Recôncavo da Bahia, Rui Barbosa street, 710, Zip Code: 44380-000, Cruz das Almas, Bahia State, Brazil

2 Center of Exact and Technological Sciences, Federal University of Recôncavo da Bahia, Rui Barbosa street, 710, Zip Code: 44380-000, Cruz das Almas, Bahia State, Brazil

\author{
Correspondence \\ ML. Cazetta \\ E-mail: malucz@ufrb.edu.br \\ Received: 12 September 2019 \\ Accepted: 13 February 2020 \\ Published on-line: 31 March 2020
}

\section{Resumen}

Bioproductos de la industria de la yuca: sustratos alternativos para la producción de ciclodextrina glucosiltransferasa por alcalófilo Bacillus trypoxylicola SM-02

En el presente trabajo estudiamos el uso licor de maíz fermentado (LMF), harina de cáscara de yuca (HCY) y aguas residuales de yuca para la producción de ciclodextina glicosiltransferasa (CGTase) por un nuevo aislado alcalófilo de Bacillus trypoxylicola SM-02 en fermentación sumergida. Los experimentos se realizaron por Diseño Central Compuesto Rotativo $2^{2}$ totalizando 11 ensayos. La mayor actividad enzimática de $352.53 \mathrm{U} / \mathrm{mL}$ se obtuvo con $1.5 \mathrm{~g}$ de HCY y $0.6 \mathrm{~g}$ de LMF. La temperatura y el $\mathrm{pH}$ óptimos fueron $55^{\circ} \mathrm{C}$ y $\mathrm{pH} 8.0$, respectivamente. CGTase mostró una actividad relativa superior al $50 \%$ durante $120 \mathrm{~min}$. a la temperatura óptima. Solo el $\mathrm{CaCl} 2$ mostró actividad positiva para CGTasa. Los resultados apuntaron a un buen potencial de B. trypoxylicola SM-02 para la producción de CGTasa usando substratos residuales.

Palabras clave: Enzima; Subproductos agroindustriales; Bacteria.

\section{Abstract}

In the present work was studied the use of cassava peel flour $(\mathrm{CPF})$, corn steep liquor (CSL), and cassava wastewater as substrates to produce cyclodextrin glycosyltransferase (CGTase) from a new alkalophilic isolate of Bacillus trypoxylicola SM-02 by submerged fermentation. The experiments were performed as a Central Composite Design $2^{2}$, totalizing 11 assays. An enzymatic activity of $352.53 \mathrm{U} / \mathrm{mL}$ was obtained using $1.5 \mathrm{~g}$ of CPF and $0.6 \mathrm{~g}$ of CSL. The optimum temperature and $\mathrm{pH}$ of CGTase was $55^{\circ} \mathrm{C}$ and 8.0 , respectively. The CGTase depicted a relative activity of more than $50 \%$ for $120 \mathrm{~min}$ at the optimum temperature. The only salt that positively influenced the CGTase activity was $\mathrm{CaCl}_{2}$. The results are indicative of a potential role of $B$. trypoxylicola SM-02 in the production of CGTase using residual substrates.

Key words: Enzyme; Agro-industrial byproducts; Bacteria. 


\section{Introduction}

An increasing interest in the study involving cyclodextrin glycosyltransferase (CGTase, EC 2.4.1.19), also known as cyclomaltodextrin glucanotransferase, has developed due to its ability to convert the starch molecules to cyclodextrins (CDs) through an intramolecular transglycosylation reaction (cyclization) (Van der Veen et al. 2000, Amud et al. 2008, Satyawali et al. 2017). Cyclodextrin glycosyltransferase is synthesized extracellularly by different microorganisms (Han et al. 2014). However, the bacteria belonging to the genus Bacillus Cohn, 1872 are most widely studied for CGTase production (Costa et al. 2015, Eş et al. 2016, Coelho et al. 2016). Cyclodextrins are characterized as cyclic oligosaccharides containing six $(\alpha-C D)$, seven $(\beta-C D)$ and eight $(\gamma-$ CD) glucopyranose units linked by $\alpha-1,4$ glycosidic linkages. The CDs are characterized by a ring of truncated cone shape consisting of a hydrophilic exterior and a hydrophobic interior surface and thus are capable of forming inclusion compounds with a wide variety of molecules (Venturini et al. 2008, Kfoury et al. 2018). The formation of inclusion compounds resulting from the merging of the $\mathrm{CD}$ ring and a guest molecule (organic and inorganic) in the liquid or eventually solid medium is known to alter the physical and chemical properties of these compounds such as an increase or decrease in the solubility, stability, color, and smell (Venturini et al. 2008). The cyclodextrins have been utilized as aroma and flavor stabilizers and for the elimination of unwanted compounds in the food industry (Arya \& Srivastava 2006), to reduce the toxicity of some drugs in the pharmaceutical industry (Nicolazzi et al. 2002), and in washing and dyeing processes in the textile industry (Andreaus et al., 2010). These are also employed in removing pollutants from the soil (Szaniszló et al. 2005, Venturini et al. 2008). In an attempt to reduce the cost of production of CGTase, some residual products found in abundance at low cost and with high nutritional content have been utilized as an alternative. This is important for the CGTase production due to the high cost of both the enzyme and the CDs. The products and by-products derived from cassava have been utilized as substrates for CGTase production. Alves-Prado et al. (2002) studied CGTase production using four strains of Bacillus sp., sub- group alcalophilus by semi-solid-state fermentation using cassava starch. This carbon source was also used in the enzyme production by Bacillus licheniformis (Weigmann, 1898) Chester, 1901, Bacillus sp. BACNC-1 and BACRP (Bonilha et al. 2006, Menocci et al. 2008). The residues from the cassava flour industry such as cassava peel and cassava wastewater and waste from the corn production such as corn steep liquor are considered as economically viable substrates with good potential for CGTase production. The cassava wastewater is considered a relatively polluting agent due to the significant amount of soluble sugars and organic matter present in it (high CDO values), besides being potentially toxic due to the presence of cyanide formed from the enzymatic hydrolysis of Lynamarin, a cyanogenic glycoside present in members of Manihot genus as cassava (Kaewkannetra et al. 2011, Zevallos et al. 2018, Watthier et al. 2019). Therefore, cassava wastewater, as a fermentative substrate may help in reducing the environmental impacts produced by inappropriate disposal of this waste besides contributing in reducing the cost of the CGTase production. In this context, the present study aimed to analyze the CGTase production using cassava wastewater and ground cassava peel as carbon sources, and corn steep liquor as a nitrogen source by submerged fermentation using a bacterial isolate obtained from cassava flour factory and identified as Bacillus trypoxylicola SM-02 (Coelho et al., 2016).

\section{Material and Methods}

\section{Bacterial strain and substrates}

Bacillus trypoxylicola SM-02 was isolated from the soil samples containing cassava wastewater from a cassava flour factory in Cruz das Almas county, Bahia, Brazil (Coelho et al. 2016). The cassava peel and cassava wastewater used as substrates in the fermentative process were also provided by cassava flour factories of Cruz das Almas county. The bacterial isolate was preserved in $20 \%$ glycerol at $-10{ }^{\circ} \mathrm{C}$. The cassava peel was washed under running water to remove the excess soil and later dried in a kiln with air circulation at $70{ }^{\circ} \mathrm{C}$ for 72 hours. After drying, the cassava peel was ground to obtain a fine powder (Cassava Peel Flour-CPF). 


\section{Molecular identification}

A pair of universal primers, 8F (5'AGAGTT TGATCCTGGCTCAG3') and 1492R (5'ACGGCTACCTTGTTACGACTT3'), was used to amplify the 16S rRNA. The sequencing was carried out commercially by Macrogen Co. (Korea). The 16S rRNA sequence was used as a query in BLASTN25 search against the National Center for Biotechnology Information (NCBI) database. MEGA 5.05 software was used to construct an evolutionary model and to generate the maximum likelihood tree. The 16S rRNA sequences used in the phylogenetic analysis were retrieved from the site of List of Prokaryotic Standing Names (LPSN) during (Coelho et al. 2016)

\section{Fermentation assays}

The pre-inoculum consisted of a basal medium as described by Nakamura \& Horikoshi (1976) containing $(\mathrm{g} / \mathrm{L})$ : soluble starch, 10 ; yeast extract, 5 ; peptone, $5 ; \mathrm{MgSO}_{4} .7 \mathrm{H}_{2}, 0.2 ; \mathrm{KH}_{2} \mathrm{PO}_{4}, 1.0$; and $\mathrm{Na}_{2} \mathrm{CO}_{3}, 10$ in distilled water. The culture of $B$. trypoxylicola SM-02 was transferred to $10 \mathrm{~mL}$ of pre-inoculum medium and maintained at $35^{\circ} \mathrm{C}$ at $150 \mathrm{rpm}$ for 24 hours. For inoculum, the starch was replaced by CPF and the nitrogen sources (yeast extract and peptone) by corn steep liquorCSL (Sigma ${ }^{\circledR}$ ) and was solubilized in cassava wastewater in place of distilled water. After an incubation of 24 hours, the pre-inoculum was transferred to $125 \mathrm{~mL}$ Erlenmeyer flasks containing 50 $\mathrm{mL}$ of inoculum medium and kept at $35{ }^{\circ} \mathrm{C}$ and $150 \mathrm{rpm}$ for 24 hours. Then, an aliquot of $1 \mathrm{~mL}$ of the inoculum (O.D. $\left.{ }_{600}=0.1\right)$ was transferred to 250 $\mathrm{mL}$ Erlenmeyer flasks containing $25 \mathrm{~mL}$ of fermentation medium according to the Central Composite Design $2^{2}$ at $35^{\circ} \mathrm{C}$ and $150 \mathrm{rpm}$ (Table 1). After 72 hours of fermentation, the samples were centrifuged at $5,000 \mathrm{rpm}, 4{ }^{\circ} \mathrm{C}$ for $30 \mathrm{~min}$. The cell-free supernatant and the biomass were used for the determination of CGTase activity and cellular growth, respectively.

\section{Optimization using Central Composite Design (CCD)}

The concentration of CPF and CSL was performed using Response Surface Methodology (RSM) according to Rodrigues \& Iema (2009). The CGTase activity $(\mathrm{U} / \mathrm{mL})$ and the substrate concentrations were as dependent (response) and independent variables, respectively. A matrix of factorial design $2^{2}$ was constructed using $\mathrm{CCD}$, resulting in 11 assays. Two levels were chosen, one superior $(+1)$ and one inferior $(-1)$, besides the center point $(0)$ and two axial points $(+1.41$ and 1.41). The central point was used with three repetitions for determining the methodological accuracy (Table 1). This model is represented by a second-order polynomial regression:

$$
y=b_{0}+b_{1} x_{1}+b_{2} x_{2}+b_{12} x_{1} x_{2}+b_{11} x_{1}^{2}+b_{22} x_{2}^{2}
$$

where $y$ is the predicted response of CGTase activity; $X_{1}$ and $X_{2}$ are code forms (cassava peel flour and corn steep liquor, respectively); $b_{0}$ refers to the intersection point; $b_{1}$ and $b_{2}$ are linear coefficients; $b_{12}$ is the coefficient of double interaction; and $b_{11}$ and $b_{22}$ are quadratic coefficients. The values of the studied levels were calculated by:

$$
X_{n}=\frac{\left(X-X_{0}\right)}{X_{+1}-X_{-1}}
$$

where, $X_{n}$ is the encoded value; $X$ is the real value of the independent variable; $X_{0}$ is the real value of the central point; $\mathrm{X}_{+1}$ is the value of the superior level, and $\mathrm{X}_{-1}$ is the value of the inferior level. The results presented by the applied experimental model were assessed through the Statistica software release version 7.1, Stat Soft. Inc., USA.

\section{Enzymatic activity}

The CGTase activity was determined by a colorimetric method using cyclodextrin-phenolphthalein complex (CD-PHE) (Suzuki et al. 1990). The reaction mixture containing $5.0 \mathrm{~mL}$ of crude enzyme extract (cell-free supernatant) and $5.0 \mathrm{ml}$ of $1 \%$ soluble starch solution was incubated in a thermostated reactor at $55^{\circ} \mathrm{C}, \mathrm{pH} 8.0$. The samples of $0.5 \mathrm{ml}$ from the reaction solution were withdrawn at $0,3,6,9$, and 12 minutes and inactivated in boiling water for 5 minutes. Then, $2.5 \mathrm{~mL}$ of an alcoholic solution of phenolphthalein (3 $\mathrm{mM}$ ) diluted in a buffer containing $600 \mathrm{mM}$ $\mathrm{Na}_{2} \mathrm{CO}_{3}$ and $\mathrm{pH} 10.5$ was added. The absorbance was read at $550 \mathrm{~nm}$. CGTase production was observed by the decreasing intensity of the pink reagent due to the formation of inclusion compounds of CDs with phenolphthalein.

\section{Cellular growth}

After fermentation, the biomass was separated by centrifugation at $5000 \mathrm{rpm}$ for 30 minutes at $4{ }^{\circ} \mathrm{C}$. The biomass was washed by suspending in $5 \mathrm{~mL}$ of distilled water and centrifuged. After removing the supernatant, the precipitate was re-suspended, 
and the optical density was measured at $600 \mathrm{~nm}$. The cellular growth was quantified by comparing with the standardized curve based on dry mass $\mathrm{x}$ optical density.

\section{Determination of Total Reducing Sugar (TRS)}

The samples were subjected to an acid hydrolysis in $2 \mathrm{M} \mathrm{HCl}$. After boiling for 20 minutes, the samples were neutralized with $2 \mathrm{M} \mathrm{NaOH}$. The total reducing sugars were determined using 3,5-dinitrosalicylic acid (DNS) method according to Miller (1959).

\section{Determination of total protein}

Total protein concentration was determined by Bradford method by adding $0.2 \mathrm{~mL}$ of the crude enzyme extract to $2 \mathrm{~mL}$ of the Bradford reagent. Absorbance was recorded at $595 \mathrm{~nm}$ (Bradford 1976)

\section{Partial characterization of crude enzyme extract}

The optimum temperature for CGTase activity was determined by incubating the crude extract containing the enzyme in the range of $45^{\circ} \mathrm{C}$ to 70 ${ }^{\circ} \mathrm{C}$ at $\mathrm{pH}$ 8.0. The thermal stability was evaluated by incubating the crude enzyme extract at $50{ }^{\circ} \mathrm{C}$, $55{ }^{\circ} \mathrm{C}$, and $60{ }^{\circ} \mathrm{C}$ in a thermostated bath for 5 hours. The determination of the optimal $\mathrm{pH}$ was performed by using different buffers at $50 \mathrm{mM}$ : glycine-HCl pH 2.0-3.0; sodium citrate $\mathrm{pH} 3.0$ 6.0; phosphate $\mathrm{pH}$ 6.0-8.0; Tris-HCl $\mathrm{pH}$ 8.0-9.0; and glycine- $\mathrm{NaOH} \mathrm{pH} 9.0-10.0$. The influence of metal ions was evaluated using the following so- lutions prepared at $50 \mathrm{mM}: \mathrm{CaCl}_{2}, \mathrm{FeCl}_{2}, \mathrm{NaCl}$, $\mathrm{ZnSO}_{4}, \quad \mathrm{EDTA}, \mathrm{KCl}, \mathrm{MnCl}_{2}, \mathrm{CuSO}_{4}, \mathrm{BaCl}_{2}$, $\mathrm{HgCl}_{2}$, and $\mathrm{MgCl}_{2}$. For control, the enzyme activity was performed using the supernatant without the addition of salts to the reaction mixture.

\section{Results}

Table 1 shows the matrix of CCD $2^{2}$ with the results of CGTase activity and biomass production using cassava peel and corn steep liquor as substrates, diluted in cassava wastewater after 72 hours of fermentation along with the values predicted by the statistical model.

The experimental conditions resulted in the highest values of CGTase activity at the center point $(9,10$, and 11) with an average activity of $352.53 \mathrm{U} / \mathrm{mL}$, using $1.5 \mathrm{~g}$ of cassava peel flour and $0.6 \mathrm{~g}$ of corn steep liquor. A similar production was observed in the assay 7 ( $1.5 \mathrm{~g}$ of cassava peel flour and $0.2 \mathrm{~g}$ of corn steep liquor) resulting in $318.25 \mathrm{U} / \mathrm{mL}$ of CGTase activity (Table 1).

However, according statistical analysis of the regression coefficients (Table 2), only the cassava peel flour in the quadratic term was statistically significant at $95 \%$ confidence level $(\mathrm{p}<0.05)$. These results indicated that the only variable that influenced CGTase activity was the carbon source. The nitrogen source (corn steep liquor) did not influence the production of CGTase ( $\mathrm{p}>0.05)$, which means that the variation in its concentration had no effect on the enzymatic activity within the studied concentration range $(0.2$ to $1.0 \mathrm{~g})$. The values for $F_{\text {calc }}$ of 15.82 and $R^{2}$ of $82.71 \%$ indicated that the results were highly significant and

\begin{tabular}{|c|c|c|c|c|c|c|c|c|}
\hline Run & Codifie & values & Real v & lues (g) & CGTase acti & tivity $(\mathrm{U} / \mathrm{mL})$ & Biomass & (g/L) \\
\hline & $\mathrm{X}_{1}$ & $\mathrm{X}_{2}$ & $\begin{array}{c}\text { Cassava peel } \\
\text { flour }\end{array}$ & Corn steep liquor & Observed values & Predicted values & Observed values & $\begin{array}{l}\text { Predicted } \\
\text { values }\end{array}$ \\
\hline 1 & -1 & -1 & 1.0 & 0.32 & 288.60 & 247.84 & 5.28 & 5.08 \\
\hline 2 & +1 & -1 & 2.0 & 0.32 & 136.67 & 202.47 & 6.17 & 7.58 \\
\hline 3 & -1 & +1 & 1.0 & 0.88 & 73.36 & 43.35 & 12.85 & 11.86 \\
\hline 4 & +1 & +1 & 2.0 & 0.88 & 122.54 & 199.10 & 5.63 & 6.25 \\
\hline 5 & -1.41 & 0 & 0.8 & 0.60 & 15.45 & 72.90 & 8.51 & 9.43 \\
\hline 6 & +1.41 & 0 & 2.2 & 0.60 & 244.20 & 150.94 & 8.59 & 7.23 \\
\hline 7 & 0 & -1.41 & 1.5 & 0.20 & 318.25 & 307.95 & 5.90 & 5.12 \\
\hline 8 & 0 & +1.41 & 1.5 & 1.00 & 186.48 & 160.97 & 8.64 & 8.98 \\
\hline 9 & 0 & 0 & 1.5 & 0.60 & 340.99 & 352.53 & 7.24 & 6.96 \\
\hline 10 & 0 & 0 & 1.5 & 0.60 & 356.97 & 352.53 & 6.97 & 6.96 \\
\hline 11 & 0 & 0 & 1.5 & 0.60 & 359.64 & 352.53 & 6.67 & 6.96 \\
\hline
\end{tabular}

Tabla 1. Matriz del Diseño Central Compuesto Rotativo $2^{2}$ que muestra valores independientes y respuestas de $B$. trypoxylicola SM-02 en fermentación sumergida a $35^{\circ} \mathrm{C}$ y $150 \mathrm{rpm}$ durante $72 \mathrm{~h}$.

Table 1. Matrix of Central Composite Design $2^{2}$ showing independent values and responses by B. trypoxylicola SM-02 in submerged fermentation at $35^{\circ} \mathrm{C}$ and $150 \mathrm{rpm}$ for $72 \mathrm{~h}$. 


\begin{tabular}{|c|c|c|c|c|}
\hline Factors & $\begin{array}{l}\text { Regression } \\
\text { coefficient }\end{array}$ & $\begin{array}{l}\text { Standard } \\
\text { error }\end{array}$ & $t(5)$ & p-value \\
\hline Mean & 352.53 & 41.40 & 8.52 & 0.000367 \\
\hline Cassava peel flour $\left({ }^{*} \mathrm{~L}\right)$ & 27.59 & 25.35 & 1.09 & 0.326070 \\
\hline Cassava peel flour $\left({ }^{* \star} Q\right)$ & -120.31 & 30.18 & -3.99 & 0.010459 \\
\hline Corn steep liquor (L) & -51.97 & 25.35 & -2.05 & 0.095678 \\
\hline Corn steep liquor (Q) & -59.04 & 30.18 & -1.96 & 0.107785 \\
\hline $\begin{array}{l}\text { Cassava peel flour } \times \\
\text { corn steep liquor }\end{array}$ & 50.28 & 35.85 & 1.40 & 0.219758 \\
\hline
\end{tabular}

${ }^{*} \mathrm{~L}=$ Linear; ${ }^{* *} \mathrm{Q}=$ Quadratic; $\mathrm{R}^{2}=0,8271$

Tabla 2. Análisis de regresión de la producción de CGTasa por $B$. trypoxylicola SM-02 en fermentación sumergida a $35^{\circ} \mathrm{C}$ y 150 rpm durante $72 \mathrm{~h}$ utilizando aguas residuales de yuca, harina de cascara de yuca y licor de maíz fermentado como sustratos.

Table 2. Regression analysis of CGTase production by $B$. trypoxylicola SM-02 in submerged fermentation at $35^{\circ} \mathrm{C}$ y 150 rpm for $72 \mathrm{~h}$ using cassava wastewater, cassava peel flour, and corn steep liquor as substrates.

\begin{tabular}{ccccc}
\hline Factors & $\begin{array}{c}\text { Freedom } \\
\text { degree }\end{array}$ & $\begin{array}{c}\text { Sum of the } \\
\text { squares (SS) }\end{array}$ & $\begin{array}{c}\text { Means squares } \\
(\mathrm{MS})\end{array}$ & $\mathrm{F}_{\text {calc }}$ \\
\hline Regression & 3 & 174414.0 & 58138.0 & $15.82^{\mathrm{a}}$ \\
Residue & 7 & 25709.4 & 3672.8 & \\
Total & 10 & 148704.6 & & \\
\hline
\end{tabular}

a Significant at $5 \%$ probability; $R^{2}: 0.8271$

Tabla 3. Análisis de varianza para la producción de CGTasa de $B$. trypoxylicola SM-02 en fermentación sumergida a $35^{\circ} \mathrm{C}$ y 150 rpm durante $72 \mathrm{~h}$ utilizando aguas residuales de yuca, harina de cascara de yuca y licor de maíz fermentado como sustratos.

Table 3. Analysis of variance for CGTase production by $B$. trypoxylicola SM-02 in submerged fermentation at $35{ }^{\circ} \mathrm{C}$ y 150 for $72 \mathrm{~h} \mathrm{rpm}$ using cassava wastewater, cassava wastewater, cassava peel flour, and corn steep liquor as substrates.

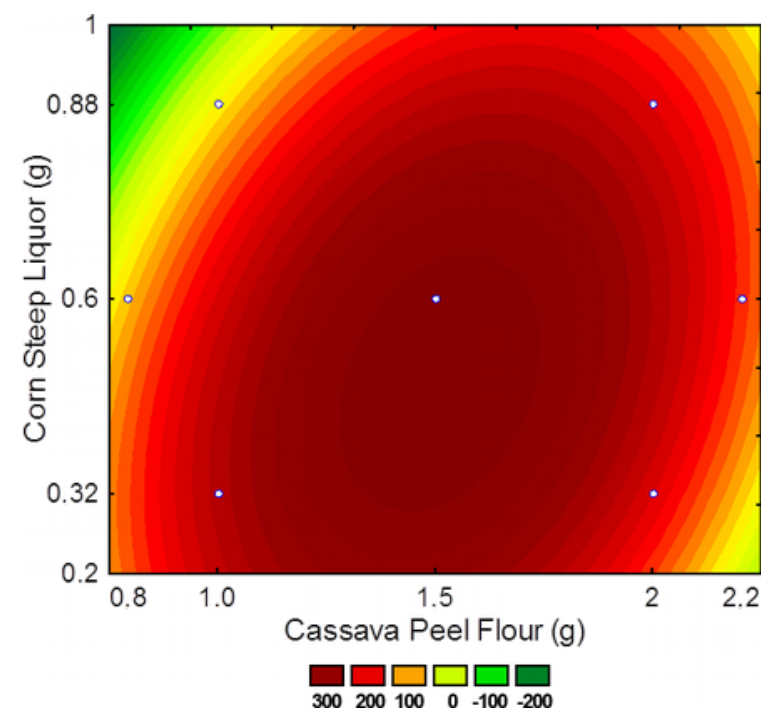

Figura 1. Diagrama de contorno para la producción de CGTasa de B. trypoxylicola SM-02 por fermentación sumergida con aguas residuales de yuca, harina cáscara de yuca y licor de maíz fermentado a $35^{\circ} \mathrm{C}$ y $150 \mathrm{rpm}$ durante $72 \mathrm{~h}$. La figura muestra desde la producción de CGTasa más pequeña (verde) hasta la mayor (rojo).

Figure 1. Contour plot for CGTase production from $B$. trypoxylicola SM-02 by submerged fermentation using cassava wastewater, cassava peel flour and corn steep liquor as substrates at $35^{\circ} \mathrm{C}$ and $150 \mathrm{rpm}$ for $72 \mathrm{~h}$. The figure shows the production of CGTase from the smallest (green) to the largest (red) value. the correlation between the predicted and observed values was good (Table 3). In this way, it can be affirmed that the results fit well with the model and the coefficient regression values could be used to generate the model equation:

Enzymatic activity $=352.53+27.59 X_{1}-120.31 X_{1}^{2}-51.97 X_{2}-59.04 X_{2}^{2}+50.28 X_{1} X_{2}$

The equation generated by the model is important because, through it, it is possible to derive the optimal conditions to determine the critical point (Rodrigues \& Iema, 2009). The chart of contour curves (Fig. 1) confirmed these results to be within the range studied for the dependent variables, and the center point region presented the highest CGTase activity. Response Surface Methodology is very useful for the modeling and the analysis of problems, where the outcome is influenced by multiple variables and the objective is the response optimization (Maddipati et al. 2011). Furthermore, this type of chart allows viewing a wide range of substrate concentrations where the enzyme production remains high. This is of importance when using wastes or agro-industrial byproducts as substrates for fermentation processes, which show considerable variation in its composition.

Under optimized conditions, CGTase production follows the exponential growth phase of $B$. trypoxylicola SM-02 until 72 hours of fermentation after which, there was a downward trend coinciding with the decline of cellular growth. At the same time, almost complete consumption of sugars was noted, which may be attributed to the metabolic activity of the bacteria after 120 hours (Fig. 2).

\section{Partial characterization of enzyme crude extract}

Physical and chemical characterization was performed using the crude enzyme extract obtained under optimized fermentation conditions. The enzyme displayed a reduced activity in acidic $\mathrm{pH}$ ranging from 2.0 to 6.0 . At the $\mathrm{pH}$ values 7.0 and 8.0, CGTase exhibited a relative activity of $80 \%$ with an optimum $\mathrm{pH}$ at 8.0. At $\mathrm{pH}$ 9.0, the enzyme activity decreased but remained above $50 \%$ until pH 10.0 (Fig. 3).

The optimum temperature of CGTase produced by $B$. trypoxylicola SM- 02 was $55^{\circ} \mathrm{C}$ with $50 \%$ relative activity at 50,60 and $65^{\circ} \mathrm{C}$ and was completely inactivated at $70{ }^{\circ} \mathrm{C}$ (Fig. 4A). In relation to thermal stability, the activity of CGTase 


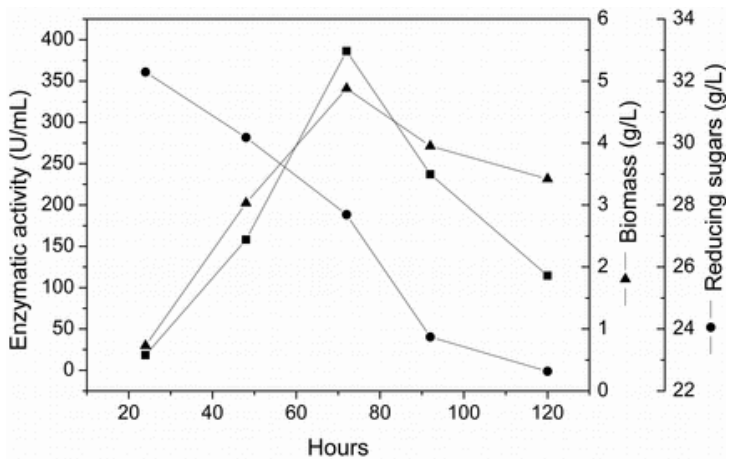

Figura 2. Fermentación sumergida en el transcurso del tiempo por B. trypoxylicola SM-02 con aguas residuales de yuca, harina cáscara de yuca y licor de maíz fermentado como substratos a 35 ${ }^{\circ} \mathrm{C}$ y $150 \mathrm{rpm}$ durante $120 \mathrm{~h}$.

Figure 2. Submerged fermentation time-course of B. trypoxylicola SM-02 using cassava wastewater, cassava peel flour, and corn steep liquor as substrates at $35^{\circ} \mathrm{C}$ and $150 \mathrm{rpm}$ for $120 \mathrm{~h}$.

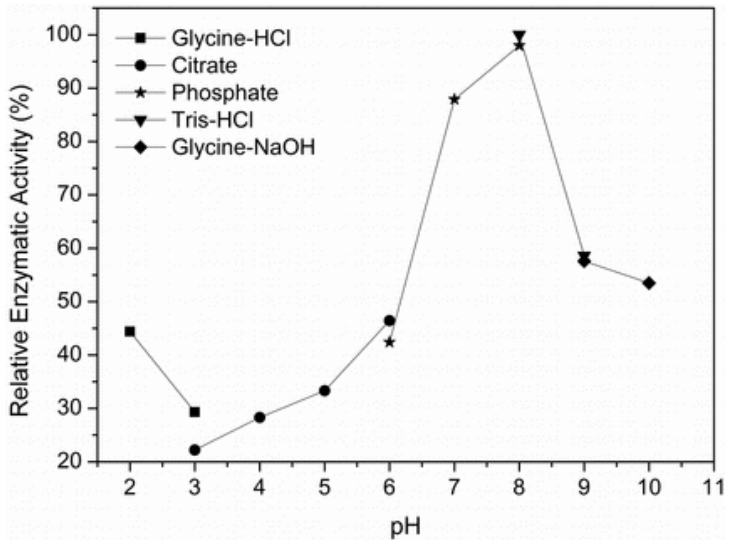

Figura 3. pH óptimo de la actividad CGTasa de B. trypoxylicola SM-02 cultivada en aguas residuales de yuca, HCY y LMF como sustratos a $35{ }^{\circ} \mathrm{C}$ y $150 \mathrm{rpm}$. La fuerza iónica para todos los tampones fue de $50 \mathrm{mM}$.

Figure 3. Optimum $\mathrm{pH}$ of CGTase activity of B. trypoxylicola SM-02 grown on cassava wastewater, $\mathrm{CPF}$, and CSL as substrates at $35^{\circ} \mathrm{C}$ and $150 \mathrm{rpm}$. The ionic strength for all buffers was 50 $\mathrm{mM}$.

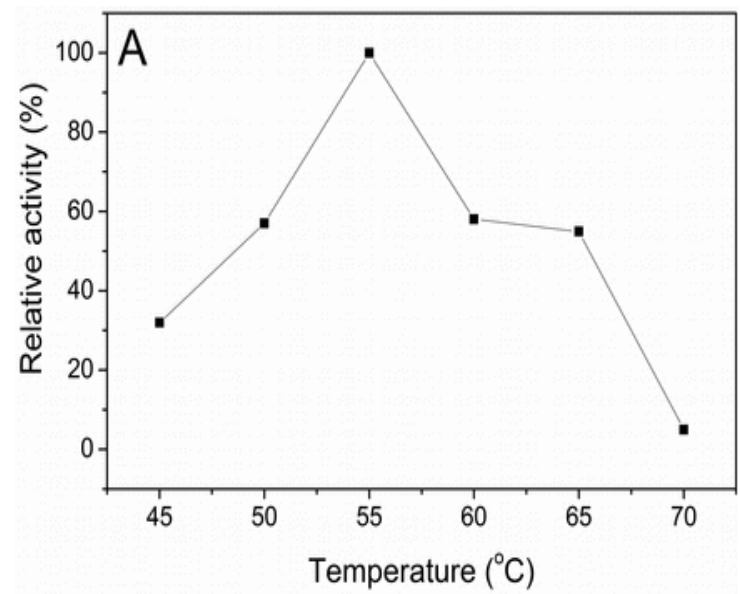

from B. trypoxylicola SM-02 presented a relative activity of $75 \%$, on average, between 30 minutes and 1 hour of incubation, and about $60 \%$ after 2 hours. After 3 hours the enzyme still showed a relative activity of about $40 \%$ at $55^{\circ} \mathrm{C}$ (Fig. 4B).

Assessing the influence of ions (Table 4), it was observed that enzyme production was positively influenced by $\mathrm{CaCl}_{2}$, which resulted in an increase in the enzyme activity compared with the control. The enzyme was weakly inhibited by $\mathrm{MgCl}_{2}, \mathrm{FeCl}_{2}, \mathrm{NaCl}$, and $\mathrm{CuSO}_{4}$ reaching an activity almost next to the control, and was strongly inhibited by EDTA, $\mathrm{BaCl}_{2}$ resulting in a drop of enzyme activity to below $75 \%$ (Table 4).

\section{Discussion}

Although there are reports of the use of the residues from cassava processing, i.e., peel and cassava wastewater in the production of other enzymes such as amylase, protease, and lipase (Barros et al. 2013), these residues have not been used for CGTase production. Agro-industry substrates are cited in the literature as best for the CGTase production, compared with the conventional synthetic substrates, whose origin is corn starch. $\mathrm{Cu}-$ colo et al. (2006) described the highest CGTase production using tapioca flour than the soluble starch. Similarly, our group also observed a high CGTase production in cassava flour by Bacillus sp. SM-02 (Coelho et al. 2016). This shows that the substrates of agricultural origin are considerably efficient for the enzyme production, possibly

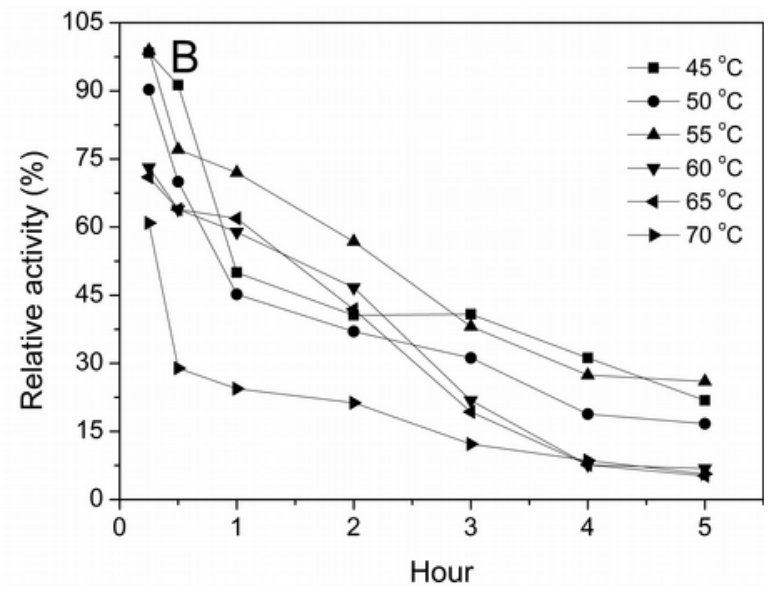

Figura 4. Temperatura óptima (a) y estabilidad térmica (b) de CGTasa producida por B. trypoxylicola SM-02 cultivada en aguas residuales de yuca, HCY y LMF como sustratos a $35^{\circ} \mathrm{C}$ y $150 \mathrm{rpm}$ durante $72 \mathrm{~h}$.

Figure 4. Optimum temperature (a) and thermal stability (b) of CGTase produced by B. trypoxylicola SM-02 02 grown on cassava wastewater, $\mathrm{CPF}$, and CSL as substrates at $35^{\circ} \mathrm{C}$ and $150 \mathrm{rpm}$ for $72 \mathrm{~h}$. 
due to a complete chemical composition of macro and micronutrients, which supplement the fermentation medium and consequently increase the CGTase production. According to Alves-Prado et al. (2008) the concentration of lipids in the starch should be considered, since it is a factor that interferes in the production of CGTase. Cassava starch presents low amount of lipids and does not form amylose-lipid complexes in root and tuber starches, unlike in cereal starches. In addition, less content of amylose (between 17\% and 20\%) than cereal starch (25 to $30 \%$ ) may explain the high CGTase production in substrates derived from cassava (Moorthy et al. 2006, Weber et al. 2009, Senanayake et al. 2013).

The nitrogen source is an important element in the CGTase production, especially when starch derived from cassava is used. This is due to the fact that there is a reduction in the enzyme production if this substrate is used without supplementation with peptone and yeast extract (Cucolo et al. 2006). Organic nitrogen sources have been found to be most suitable compared to the inorganic ones and peptone and yeast extract are the most used nitrogen sources (Mahat et al. 2004, Ibrahim et al. 2005, Cucolo et al. 2006, Avci \& Dömnez 2009). In this work, however, we chose to use the corn steep liquor as an interesting alternative due to its low cost, as it is a residue from the corn processing industry. The corn steep liquor is a nitrogen source widely used in fermentation processes for the production of different substances like enzymes (cellulase, laccase) (Wang et al. 2014, Ladeira et al. 2015), organic acids (succinic acid, lactic acid) (Lee et al. 2000, Xi et al. 2013, Wang et al. 2015), fuels (butanediol, ethanol) (Maddipati et al. 2011, Yang et al. 2013) and exopolysaccharides (Sharma et al. 2013). Corn steep liquor contains a mixture of reducing sugars and amino acids as well as water-soluble vitamins and minerals and, therefore, serves as an excellent nutrient source (Xiao et al. 2012, Xiao et al. 2013).

The profile of submerged fermentation timecourse of B. trypoxylicola SM-02 (Fig. 2) shows that the decrease in the cellular growth and consequently the enzyme activity after 72 hours seems to be related to the low concentration of sugars in the medium. This suggests that it is necessary to maintain a high concentration of sugars in the medium for high enzyme production, which can be obtained with the use of fed-batch fermentation processes that constantly feed the system with the substrates. A similar kinetic behavior was observed in other studies on CGTase production with different species of Bacillus such as Bacillus sp. H25 and Bacillus sp. subgroup alcalophilus (E16, H27, and H54) (Alves-Prado et al. 2002), where the enzyme synthesis began in the exponential phase; however, the maximum production was achieved in the stationary phase.

B. trypoxylicola SM-02 showed an optimum $\mathrm{pH}$ for the enzymatic activity in an alkaline $\mathrm{pH}$ range, indicating that this bacterium is alkalophilic (Fig. 3). CGTases produced by different species of Bacillus exhibited an optimum $\mathrm{pH}$ in the neutral and alkaline range with a few exceptions in the acidic range (Alves-Prado et al. 2002, Freitas et al. 2004, De Souza et al. 2013, Blanco et al. 2014). CGTase production in alkaline $\mathrm{pH}$ is advantageous because it reduces the tendency of starch gelatinization, which decreases the stickiness of starch at high concentration in the fermentation medium (Goo et al. 2014). Although the catalytic properties of CGTase are strongly affected by the composition of the fermentation medium, the optimum temperature between $50{ }^{\circ} \mathrm{C}$ and $55^{\circ} \mathrm{C}$ is a characteristic of several species of Bacillus producing CGTase using different substrates (Gawande et al. 2003, Freitas et al. 2004, Cucolo et al. 2006, Ibrahim et al. 2012).

The thermal stability of CGTase from B. trypoxylicola SM-02 was very good, remained above of $50 \%$ after 2 hours (Fig. 4). This behavior is similar to that described for CGTase de B. trypoxylicola $\mathrm{SM}-02$ obtained using cassava flour as a carbon source (Coelho et al., 2016). Thermostability is a further desired property of a CGTase since a higher reaction temperature reduces the viscosity of the starch substrate and can result in higher yields of ciyclodextrin (Sonnendecker \& Zimmermann 2019).

The information about ions that affect the enzymatic activity is important for the choice of substrates used in the fermentation process because depending on the composition, they may positively or negatively influence the enzyme synthesis. It is already a well-established fact that some ions act as essential enzymatic cofactors for the process of catalysis in some enzymes. The literature mentions the ions $\mathrm{Mn}^{2+}$ and $\mathrm{Mg}^{2+}$ as positive inducers of CGTase production by species of Bacillus, whereas $\mathrm{Cu}, \mathrm{Co}$, and $\mathrm{Hg}$ inhibit the enzyme activity. Some ions such as $\mathrm{Fe}, \mathrm{Ba}^{2+}$ and 
$\mathrm{Zn}$ displayed both an increase and decrease in the cyclization activity of the enzyme depending on the Bacillus species (Freitas et al. 2004, Arya \& Srivastava 2006, Singh et al. 2010, MartínezMora et al. 2012, Ibrahim et al. 2012). For B. trypoxylicola $\mathrm{SM}-02, \mathrm{CaCl}_{2}$ was the only salt that increased enzymatic activity (Table 4). CGTase belongs to the $\alpha$-amylase superfamily and these enzymes have regions that contain highly conserved amino acid residues located in or close to the active site, and that act directly on the cleavage of the glycosidic bond, bonding to the substrate, stabilizing the transition state and binding of calcium ions. Some of these enzymes, including CGTase, contain aspartic acid residues responsible for binding calcium ions and, apparently, these conserved sequences are related to the maintenance of the enzyme's catalytic site structure (Janecek, 2002, Matsuura 2002). In addition, Saboury (2002), studying the interaction of Bacillus amyloliquefaciens $\alpha$-amylase (BAA) with divalent calcium observed that the binding of calcium stabilized the enzyme against surfactant and thermal denaturation, preventing spontaneous decrease in biological activity of $\alpha$-amylase. EDTA, in turn, is a chelating agent that can combine with several mineral ions, including calcium, which may explain the decrease of about $70 \%$ of the enzymatic activity in the presence of this compound.

\section{Conclusions}

Cassava peel four, cassava wastewater, and corn steep liquor could be considered as promising substrates for CGTase production by B. trypoxylicola SM-02 by submerged fermentation. The produced enzyme exhibited attractive features for industrial applications. It has an optimum alkaline $\mathrm{pH}$ that provides a lower risk of contamination by most competing microorganisms. Furthermore, the optimum temperature of CGTase $\left(55^{\circ} \mathrm{C}\right)$ produced by $B$. trypoxylicola SM-02 and its good thermostability facilitate the use of this enzyme in industrial processes. The use of cassava wastewater as a substrate for the fermentation processes would also help reduce the environmental impacts caused by the inappropriate disposal of this waste into the environment and the use of cassava peel can generate a new alternative of this residue. It is possible to decrease the CGTase production cost because the carbon sources involved in the study are characterized as abundant and low-cost and, in addition, have a high content of nutrients, allowing the generation of economically viable processes.

\section{Acknowledgments}

The authors thank the Higher Education Personnel Improvement Coordination (CAPES) and Bahia State Research Support Foundation (FAPESB) for financial support.

\section{References}

Alves-Prado HF, Hilário E, Gomes E \& Da Silva R. 2002. Seleção de microrganismos produtores de ciclodextrina glicosiltransferase (CGTase), produção e caracterização da enzima. Brazilian Journal of Food Technology 5: 189-196.

Alves-Prado HF, Carneiro AAJ, Pavezzi FC, Gomes E, Boscolo M, Franco CML \& Da Silva R. 2008. Production of cyclodextrins by CGTase from Bacillus clausii using different starches as substrate. Applied Biochemistry and Biotechnology 146(1-3): 3-13. https://doi.org/10.1007/s12010-007-8093-z

Andreaus J, Dalmolin MC, Oliveira Junior IB \& Barcellos IO. 2010. Aplicação de ciclodextrinas em processos têxteis. Química Nova 33(4) 929-937. https://doi.org/ 10.1590/S0100-40422010000400031

Arya SK \& Srivastava SK. 2006. Kinetics of immobilized cyclodextrin gluconotransferase produced by BaciIlus macerans ATCC 8244. Enzyme Microbial Technology 39(3): 507-510. https://doi.org/10.1016/j.enz mictec.2005.12.019

Avci A \& Dömnez S. 2009. A novel thermophilic anaerobic bacteria producing cyclodextrin glycisyltransferase. Process Biochemistry. 44:36-42 https://doi. org/10.1016/j.procbio.2008.09.006

Barros FFC, Simiqueli APR, De Andrade C,J \& Pastore GM. 2013 Production of enzymes from agroindustrial wastes by biosurfactant-producing strains of $\mathrm{Ba}-$ cillus subtilis. Biotechnology Research International 2013: ID 103960 [9]. https://doi.org/10.1155/2013/ 103960

Blanco KC, Moraes FFD, Bernardi NS, Vettori B, Palmuti MH, Monti R \& Contiero J. 2014. Cyclodextrin production by Bacillus lehensis isolated from cassava starch: Characterisation of a novel enzyme. Czech Journal of Food Science 32(1): 48-53.

Bonilha PRM, Menocci V, Goulart AJ, Polizeli MLTM \& Monti R. 2006. Cyclodextrin glycosyltransferase from Bacillus licheniformis: optimization of production and its properties. Brazilian Journal of Microbiology 37(3): 317-323. https://doi.org/10.1590/S151783822006000300022.

Bradford MM. 1976. A rapid and sensitive method for the quantitation of microgram quantities of protein utilizing the principle of protein-dye binding. Analytical Biochemistry 72(1-2): 248-254. https://doi.org/10.10 
06/abio.1976.9999

Coelho SLA, Magalhães VC, Marbach PAS \& Cazetta ML. 2016. A new alkalophlic isolate of Bacillus as a producer of cyclodextrin glycosyltransferase using cassava flour. Brazilian Journal of Microbiology 47(1): 120-8. https://dx.doi.org/10.1016/Fj.bjm.2015 .11 .018

Costa H, Gastón JR, Lara J, Martinez CO, Moriwaki C, Matioli G \& Ferrarotti AS. 2015. Cyclodextrin glycosyltransferase production by free cells of Bacillus circulans DF 9R in batch fermentation and by immobilized cells in a semi-continuous process. Bioprocess and Biosystems Enginnering 38(6): 1055-1063. https://doi.org/10.1007/s00449-014-134 7-6

Cucolo GR, Alves-Prado HF, Gomes E \& Da Silva R. 2006. Otimização da produção de CGTase de Bacillus $\mathrm{sp}$ subgrupo alcalophilus E16 em polvilho doce em fermentação submersa. Brazilian Journal of Microbiology 9(3): 201-208. https://doi.org/10.5151/ chemeng-cobeq2014-1694-18005-162980

De Souza M, De Faria SHB, Zanin GM \& Moraes FF. 2013. Kinetics of the simultaneous production of band g-cyclodextrins catalyzed by CGTase from alkalophilic Bacillus sp. Acta Scientiarum Technology 35(4): 687-693. https://doi.org/10.4025/actascitech nol.v35i4.13944

Eş I, Ribeiro M, Santos Júnior S, Khaneghah A, Rodriguez A \& Amaral A. 2016. Production of cyclodextrin glycosiltransferase by immobilized Bacillus sp. on chitosan matrix. Bioprocess and Biosystems Engineering 39(10): 1487-1500. https://doi.org/10.1007/ s00449-016-1625-6

Freitas TL, Monti R \& Contiero J. 2004. Production of CGTase by a Bacillus alkalophilic CGIl strain isolated from wastewater of a manioc flour industry. Brazilian Journal of Microbiology 35(3): 255-260. https://doi.org/10.1590/S1517-3822004000200015

Gawande BN, Sonawane AM, Jogdand VV \& Patkar AY. 2003. Optimization of cyclodextrin glycosyltransferase production from Klebsiella pneumoniae AS-22 in batch, fed-batch, and continuous cultures. Biotechnology Progress 19(6): 1697-1702. https:// doi.org/10.1021/bp034115t

Goo BG, Hwang YJ \& Park JK. 2014. Bacillus thuringiensis: a specific gamma-cyclodextrin producer strain. Carbohydate Research 386: 12-17. https:// doi.org/10.1016/j.carres.2013.12.005

Han R, Li J, Shin H-D, Chen RR, Du G, Liu L \& Chen J. 2014. Recent advances in discovery, heterologous expression, and molecular engineering of cyclodextrin glycosyltransferase for versatile applications. Biotechnology Advances 32(2): 415-428. https:// doi.org/10.1016/j.biotechadv.2013.12.004

Ibrahim HM, Yusoff WMW, Hamid AA, Illias RM, Hassan O \& Omar O. 2005. Optimization of medium for the production of $\beta$-cyclodextrin glucanotransferase $u$ sing Central Composite Design (CCD). Process Biochemistry 40(2): 753-758. https://doi.org/10.1016/ j.procbio.2004.01.042

Ibrahim ASS, Al-Salamah AA, El-Tayeb MA, El-Badawi YB \& Antranikian G. 2012. A novel cyclodextrin gly- cosyltransferase from alkaliphilic AmphiBacillus sp. NPST-10: Purification and properties. International Journal of Molecular Science 13(8): 10505-10522. https://dx.doi.org/10.3390/ijms130810505

Janecek S. 2002. How many conserved sequence regions are there in the a-amylase family? Biologia, Bratislava 57(11): 29-41.

Kaewkannetra P, Chiwes W \& Chiu TH. 2011. Treatment of cassava mill wastewater and production of electricity through microbial fuel cell technology. Fuel 90(8): 2746-2750. https://doi.org/10.1016/j.fuel.2011 .03 .031

Kfoury M, Landy D \& Fourmentin S. 2018. Characterization of Cyclodextrin/Volatile Inclusion Complexes: A review. Molecules 23: 1204-1227. https://dx.doi.org/ 10.3390/molecules23051204

Ladeira SA, Cruz E, Delatorre AB, Barbosa JB \& Martins MLL. 2015. Cellulase production by thermophilic Bacillus sp: SMIA-2 and its detergent compatibility. Electronic Journal of Biotechnology 18(2): 110-115. https://doi.org/10.1016/j.ejbt.2014.12.008

Lee C, Lee WG, Lee SY, Chang HN \& Chang YK. (2000). Fermentative production of succinic acid from glucose and corn steep liquor by Anaerobiospirillum succiniciproducens. Biotechnology Bioprocess Engineering 5(5): 379-381. https://doi.org /10.1007/BF02942216

Maddipati P, Atiyeh HK, Bellmer DD \& Huhnke RL. 2011. Ethanol production from syngas by Clostridium strain P11 using corn steep liquor as a nutrient replacement to yeast extract. Bioresource Technology 102(11): 6494-6501. https://doi.org/10.1016/j.biorte ch.2011.03.047

Mahat MK, Illias RM, Rahman RA, Rashid NAA, Mahmood NAN, Hassan O, Aziz SA \& Kamaruddin K. 2004. Production of cyclodextrin glucanotransferase (CGTase) from alkalophilic Bacillus sp. TS1-1: media optimization using experimental design. Enzyme Microbial Technology 35(5): 467-473. https://doi.org/ 10.1016/j.enzmictec.2004.07.008

Matsuura Y. (2002). A possible mechanism of catalysis involving threeessential residues in the enzymes of a-amylase family. Biologia, Bratislava 57(11): 21-27.

Menocci V, Goulart AJ, Adalberto PR, Tavano OL, Marques DP, Contiero J \& Monti R. 2008. Cyclodextrin glycosyltransferase production by new Bacillus sp. strains isolated from Brazilian soil. Brazilian Journal of Microbiology 39(4): 682-688. https://dx. doi.org/10.1590/S1517-838220080004000016

Miller GL. 1959. Use of dinitrosalicylic acid reagent for determination of reducing sugar. Analytical Chemistry 31(3): 426-428. https://doi.org/10.1021/ac601 47a030

Moorthy SN, Andersson L, Eliasson A-C, Santacruz S \& Ruales J. 2006. Determination of amylose content in different starches using modulated differential scanning calorimetry. Starch-Starke 58(5): 209-214. https://doi.org/10.1002/star.200500438

Martínez-Mora MMM, Hernández-Sánchez K, Villalonga-Santana R, Pérez-Rojas A, Ramírez HL \& Torres-Labandeira JJ. 2012. Partial purification and properties of cyclodextrin glycosiltransferase 
(CGTase) from alkalophilic Bacillus species. Springerplus 1(1): 1-6. https://doi. org/10.1186/2193-18011-61

Nakamura N \& Horikoshi K. 1976. Characterization and some cultural conditions of a cyclodextrin glycosyltransferase-producing alkalophilic Bacillus sp. Agricultural and Biological Chemstry 40(4): 753-757. https://doi.org/10.1080/00021369.1976.10862122

Nicolazzi C, Venard V, Le Faou A \& Finance C. 2002. In vitro antiviral efficacy of the ganciclovir complexed with $\beta$-cyclodextrin on human cytomegalovirus clinical strains. Antiviral Research 54(2): 121-127. https://doi.org/10.1016/s0166-3542(01)00218-2

Rodrigues MI \& lemma AF. 2009. Planejamento de experimentos e otimização de processos. Campinas, Brasil: Editora Casa do Pão.

Saboury AK. (2002). Stability, activity and binding properties study of $\alpha$-amylase upon interaction with $\mathrm{Ca}^{2+}$ and $\mathrm{Co}^{2+}$. Biologia, Bratislava 57(11): 221-228.

Satyawali Y, Vanbroekhoven K \& Dejonghe W. 2017. Process intensification: The future for enzymatic processes? Biochemistry Engineering Journal 121:196223. https://doi.org/10.1016/j.bej.2017.01.016

Senanayake SA, Ranaweera KKDS, Gunaratne A \& Bamunuarachchi A. 2013. Comparative analysis of nutritional quality of five different cultivars of sweet potatoes (Ipomea batatas (L) Lam) in Sri Lanka. Food Science and Nutrition 1(4): 284-291. https://doi.org/10.1002/fsn3.38

Sharma N, Prasad GS \& Choudhury AR. 2013. Utilization of corn steep liquor for biosynthesis of pullulan, an important exopolysaccharide. Carbohydate Polymer 93(1): 95-101. https://doi.org/10.1016/j.carbpol. 2012.06.059

Singh R, Bharti N, Madan J \& Hiremath SN. 2010. Characterization of cyclodextrin inclusion complexes - A review. Journal of Pharmceutical Science and Technology 2(3): 171-183.

Sonnendecker C \& Zimmermann W. 2019. Domain shuffling of cyclodextrin glucanotransferases for tailored product specificity and thermal stability. FEBS Open Bio 9:384-395. https://dx.doi.org/10. 1002/2211-5463.12588

Suzuki T, Yamane T \& Shimizu S. 1990. Phenomenological background and some preliminary trials of automated substrate supply in ph-stat modal fedbatch culture using a setpoint of high limit. Journal of Fermentation Technology 69: 292-297. https://doi. org/10.1016/0922-338X(90)90108-9

Szaniszló N, Fenyvesi É \& Balla J. 2005. Structure study of cyclodextrin complexes with selected volatile hydrocarbon contaminats of soils. Journal of Inclusion. Journal of inclusion phenomena and macrocyclic chemistry 53(3): 241-248. https://doi.org/10. 1007/s10847-005-0245-6

Van der Veen BA, Van Alebeek GWM, Uitdehaag JCM, Dijkstra BW \& Dijkhuizen L. 2000. The three transgycosilation reactions catalyzed by cyclodextrin glycosyltransferase from Bacillus circulans (strain 251) proceed via different kinetic mechanisms. European Journal of Biochemistry 267(3): 658-665. https://doi.org/10.1046/j.1432-1327.2000.01031.x

Venturini CG, Nicolini J, Machado C \& Machado VG. 2008. Propriedades e aplicações recentes das ciclodextrinas. Química Nova 31(2): 360-368. https://doi. org/10.1590/S0100-0422008000200032

Xi YL, Chen KQ, Dai WY, Ma JF, Zhang M, Jiang M \& Ouyang PK. 2013. Succinic acid production by Actinobacillus succinogenes NJ113 using corn steep liquor powder as nitrogen source. Bioresourse Technology 136: 775-779. https://doi.org/10.1016/j.bior tech.2013.03.107

Xiao X, Hou Y, Du J, Liu Y, Liu Y, Dong L, . . . Luo G. 2012. Determination of main categories of components in corn steep liquor by near-infrared spectroscopy and partial least-squares regression. Journal of Agricultural and Food Chemistry 60(32): 78307835. https://doi.org/10.1021/jf3012823

Xiao X, Hou Y, Liu Y, Liu Y, Zhao H, Dong L, . . L Luo G. 2013. Classification and analysis of corn steep liquor by UPLC/Q-TOF MS and HPLC. Talanta 107: 344348. https://doi.org/10.1016/j.talanta.2013.01.044

Wang F, Hu JH, Guo C \& Liu CZ. 2014. Enhanced laccase production by Trametes versicolor using corn steep liquor as both nitrogen source and inducer. Bioresource Technology 166: 602-605. https://doi. org/10.1016/j.biortech.2014.05.068

Wang Y, Cai D, He M, Wang Z, Qin P \& Tan T. 2015. Open fermentative production of L-lactic acid using white rice bran by simultaneous saccharification and fermentation. Bioresource Technology 198: 664-672. https://doi.org/10.1016/j.biortech.2015.09.010

Watthier E, Andreani CL, Torres DGB, Kuczman O, Tavares MHF, Lopes DD \& Gomes SD. 2019. Cassava wastewater treatment in fixed-bed reactors: organic matter removal and biogas production. Frontiers in Sustainable Food Systems 3: article 6, [8]. https:// doi.org/10.3389/fsufs.2019.00006

Weber FH, Collares-Queiroz FP \& Chang YK. 2009. Caracterização físico-química, reológica, morfológica e térmica dos amidos de milho normal, ceroso e com alto teor de amilose. Ciência e Tecnologia de Alimentos 29(4): 748-753. https://doi.org/10.1590/S0 101-20612009000400008

Yang TW, Rao ZM, Zhang X, Xu MJ, Xu ZH \& Yang ST. 2013. Effects of corn steep liquor on production of 2 , 3-butanediol and acetoin by Bacillus subtilis. Process Biochemistry 48(11): 1610-1617. https://doi. org/10.1016/j.procbio.2013.07.027

Zevallos DMP, Querol MP \& Ambrogi BG. 2018. Cassava wastewater as a natural pesticide: Current knowledge and challenges for broader utilization. Annals of Applied Biology 173: 191-201. https://doi. org/10.1111/aab.12464 